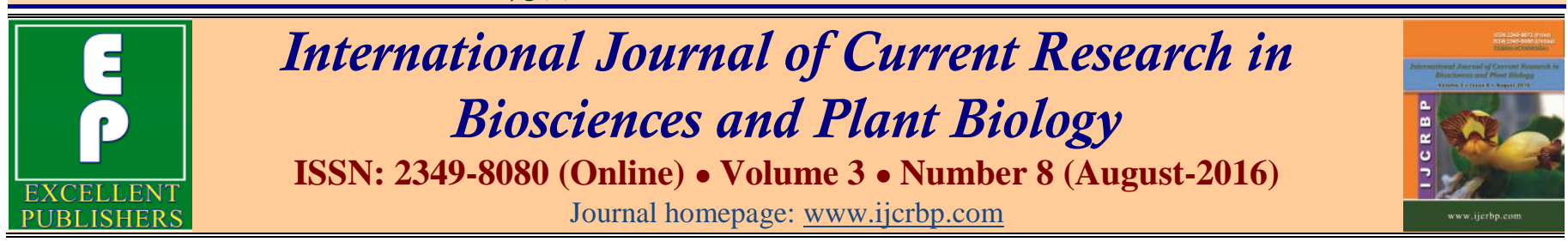

\title{
Effect of Protein - Phytate Interactions on the Solubility of Ricinodendron heudelotii (Bail.) and Tetracarpidium conophorum (Müll. Arg.) Defatted Flours
}

\author{
L. B. Mezajoug Kenfack* ${ }^{*}$ D. Tapimali Tsamé and C. Tchiégang \\ Bioprocess Laboratory, Unit of Food Sciences and nutrition, University Institute of Technology, University of Ngaoundere, \\ Cameroon P.O. Box 455, Ngaoundere-Cameroon
}

*Corresponding author.

\begin{tabular}{|c|c|}
\hline Abstract & Article Info \\
\hline \multirow{8}{*}{$\begin{array}{l}\text { Ricinodendron heudelotii and Tetracarpidium conophorum are two non - conventional } \\
\text { oleaginous plants belonging to the Euphorbiaceae family. Their kernels contain more } \\
\text { than } 20 \% \text { of proteins and are part of the food habit of Cameroonian. This study was } \\
\text { undertaken to define high solubility conditions of protein corresponding to the lesser } \\
\text { phytate solubility. Hence, the influence of } \mathrm{pH} \text {, ionic strength }\left(\mathrm{CaCl}_{2}\right) \text { and temperature on } \\
\text { protein and phytate solubility of the defatted flours were studied following a factorial } \\
\text { design between } \mathrm{pH} 4 \text { and } 9 \text {. Results revealed that protein solubility increases, whereas } \\
\text { phytate solubility decreases with the } \mathrm{pH} \text { increase. The } \mathrm{pH} \text { range }(4-9) \text { used in this } \\
\text { experiment significantly }(p<0.05) \text { influenced protein and phytate solubility of the two } \\
\text { defatted flours. Maximum solubility conditions of protein }(42-52 \mathrm{~g} \%) \text { corresponding to } \\
\text { the lowest phytate solubility ( } 50-53 \mathrm{mg} \%) \text { were } \mathrm{pH} 9, \mathrm{CaCl}_{2} 0.3 \mathrm{M} \text { and } 35^{\circ} \mathrm{C} \text {. } \\
\text { Applications of these conditions reduced protein - phytate interactions and gave protein } \\
\text { extracts with low phytate content. }\end{array}$} & $\begin{array}{l}\text { Accepted: 07 July } 2016 \\
\text { Available Online: 06 August } 2016\end{array}$ \\
\hline & Keywords \\
\hline & Defatted flours \\
\hline & \\
\hline & \\
\hline & \\
\hline & $\begin{array}{l}\text { Solubility } \\
\text { Tetracarpidium conophorum }\end{array}$ \\
\hline & \\
\hline
\end{tabular}

\section{Introduction}

Solubility is one of the physico-chemical properties used in food technology. This functionality is used to valorize many food components including protein which serves as functional ingredients in food systems. Solubility is also required in extraction and purification of proteins (Moure et al., 2006). Protein extraction are affected by many parameters like $\mathrm{pH}$, ionic strength, temperature, nature of solvent, flour /solvent ratio, flour particle size, interactions between protein and others food components such as phenolic compounds, oxalates and phytates (Godon, 1996). Interactions between protein and other compounds like phytates reduce protein extraction (Greiner et al., 2006). In the aim of increasing protein recovery during extraction, many studies on conventional protein sources like Helianthus sp (Bulmaga et al., 1989), Psophocarpus tetragonolobus (Sri Kantha et al., 1986) were realized in sight of reducing the formation of protein - phytate complexes.

In the whole world especially in the developing countries, protein extraction could lead to search of new protein sources to solve malnutrition problems.

Ricinodendron heudelotii (Bail.) and Tetracarpidium conophorum (Müll. Arg.), belonging to the Euphorbiaceae family are two non conventional oil and protein sources. $R$. heudelotii grow in Cameroon, Madagascar, Nigeria, Congo, Gabon, Ivoiry Cost and their kernels are used as soup thickener. T. conophorum grow in Cameroon, Nigeria and fruits are used as "mouth 
fruits". In western Cameroon, T. conophorum fruit is called ngak while $R$. heudelotii kernel is commonly known as njansang. The kernels of $R$. heudelotii and $T$. conophorum and their defatted flours contain more than 20 and 50\% proteins respectively (Tchiégang et al., 2006). Therefore, the exploitation of these two plants through protein extraction is necessary. In this way, the solubility in sight of extracting the protein of the two plants was studied (Mezajoug Kenfack, 2010), but the effect of phytate on the extraction was not investigated. To increase the information on protein extraction of defatted flours of the two plants, the aim of this study was to define the solubility conditions corresponding to the lowest - protein phytate complexes using factorial design.

\section{Materials and methods}

\section{Materials}

T. conophorum seeds purchased from a local market (Melong, Cameroon) were boiled and sundried, dehulled manually to obtain kernels. Cooked and dried $R$. heudelotii kernels were purchased from Ngaoundéré market (Cameroon). T. conophorum kernels were pounded in the mortar for $15 \mathrm{~min}$ to reduce the particles sizes before grinding manually with millstone (Moulinex, France) while $R$. heudelotii kernels were ground directly with the same apparatus. After extraction of fat with hexane in a Soxhlet apparatus, the resulting defatted flours were dried in open air and in oven ventilated at $45^{\circ} \mathrm{C}$ for $2 \mathrm{hrs}$ respectively. Both samples were ground and sieved through a $500 \mu \mathrm{m}$ size (AFNOR). Defatted flours with the particles size lower than $500 \mu \mathrm{m}$ were used for subsequent analyses.

\section{Chemical analyses}

Moisture, ash and crude fiber contents were determined (AOAC, 1999). Total sugars where extracted and measured (Dubois et al., 1956). Nitrogen was mineralized by Kjeldhal method and the ammonium sulfate (Devani et al., 1989). Total protein was calculated as $\mathrm{N} \times 6.25$. Phytate (Vaintraub and Lapteva, 1988) and total phenolic compounds (Makkar et al., 1993) were extracted and assessed.

\section{Solubility procedure}

Experimental design for solubility: Factorial design (Goupy and Creighton, 2006) was used to study the protein and phytate solubility of the defatted flours. $\mathrm{pH}$
$\left(X_{1}\right)$, temperature $\left(X_{2} ;{ }^{\circ} \mathrm{C}\right)$ and concentration of $\mathrm{NaCl}$ or $\mathrm{CaCl}_{2}$ solutions $\left(X_{3} ; \mathrm{mol} / \mathrm{L}\right)$ were chosen as independent variables as shown in Tables 1 and 2.

Table 1. Independent variables in the experimental plan.

\begin{tabular}{llll}
\hline \multirow{2}{*}{ Variables } & \multicolumn{3}{l}{ Coded levels } \\
\cline { 2 - 4 } & $\mathbf{- 1}$ & $\mathbf{0}$ & $\mathbf{1}$ \\
\hline $\mathrm{pH} ;\left(X_{l}\right)$ & 4 & 6.5 & 9 \\
$\mathrm{~T}\left(X_{2} ;{ }^{\circ} \mathrm{C}\right)$ & 35 & 47.5 & 60 \\
{$[$ Salt $]\left(X_{3} ; \mathrm{mol} / \mathrm{L}\right)$} & 0.3 & 0.7 & 1.1 \\
\hline [Salt $]=$ concentration of salt, $\mathrm{T}=$ temperature
\end{tabular}

Table 2. Factorial design (FD).

\begin{tabular}{lccc}
\hline Runs & $\boldsymbol{X}_{\mathbf{1}}$ & $\boldsymbol{X}_{\mathbf{2}}$ & $\boldsymbol{X}_{\mathbf{3}}$ \\
\hline 1 & -1 & 1 & 1 \\
2 & 1 & 1 & 1 \\
3 & -1 & -1 & 1 \\
4 & 1 & -1 & 1 \\
5 & -1 & 1 & -1 \\
6 & 1 & 1 & -1 \\
7 & -1 & -1 & -1 \\
8 & 1 & -1 & -1 \\
9 & 0 & 0 & 0 \\
10 & 0 & 0 & 0 \\
\hline
\end{tabular}

Percent solubility of protein or phytate was used as the dependent output variable. The independent variables $X_{i}$ were coded as $x_{i}$ according to equation (Moure et al., 2006).

$$
x_{i}=\left(X_{i}-X_{i}\right) / \Delta \bar{X}(i=1,2,3, \ldots, \mathrm{k})
$$

Where, $x_{i}$ is the dimensionless value of an independent variable; $X_{i}$ is the real value of an independent variable; $X_{i}$ is the real value of the independent variable at the center point and $\Delta X$, the step change.

For each independent variable (factor), the range selection was based on data from the literature. A $2^{3}$ factorial design, with two replications at the center points $\left(n_{o}=2\right)$, leading to a total number of 10 experiments (Table 2) was employed for the study of solubility of the defatted flours. The first degree polynomials (equation 2) were calculated using Statgraphics Centurion XVI to estimate the effects of the factors on the response. The general form of the first degree polynomial equation is (Goupy and Creighton, 2006):

$$
Y_{i}=b_{0}+\sum b_{i} X_{i}+\sum b_{i j} X_{i} X_{j}
$$

Where, $Y_{i}$ is the predicted response, $b_{0}$ is the constant term; $b_{i}$ and $b_{i j}$ are constant coefficients of linear $\left(X_{i}\right)$ and interactive $\left(X_{i} X_{j}\right)$ terms respectively. 
Analytical methods: The effects of $\mathrm{pH}\left(X_{1}\right)$, temperature $\left(X_{2}\right)$ and salt concentration $\left(X_{3}\right)$ were measured using factorial design (González-Pérez et al., 2005) with few modifications (Table 2). Defatted flours $(1 \% \mathrm{w} / \mathrm{v})$ were mixed with $\mathrm{NaCl}$ or $\mathrm{CaCl}_{2}$ solutions $(0.3 ; 0.7 ; 1.1 \mathrm{M})$ and the $\mathrm{pH}$ was kept at $4 ; 6.5$ and 9 using $0.31 \mathrm{~N} \mathrm{NaOH}$ or $0.2 \mathrm{M} \mathrm{HCl}$ while stirring for $20 \mathrm{~min}$ at $35 ; 47.5$ and $60^{\circ} \mathrm{C}$. The suspensions were then centrifuged at $3500 \mathrm{rpm}$ for $15 \mathrm{~min}$ and the supernatants were used for determination of protein $(\mathrm{N} \times 6.25)$ (Devani et al., 1989) and phytate contents (Vaintraub and Lapteva, 1988). Protein or phytate solubility was expressed as the percentage of total protein $(\mathrm{N} \times 6.25)$ or total phytate in the soluble fraction using the following formulas:

$$
\begin{aligned}
& \% \text { Soluble protein }=\frac{\text { Soluble protein } \times 100}{\text { Total protein }} \\
& \% \text { Soluble phytate }=\frac{\text { Soluble phytate } \times 100}{\text { Total phytate }}
\end{aligned}
$$

Statgraphics centurion, version $\mathrm{XV}$ was used to performed the analysis of variance (ANOVA) and the coefficient of determination $\left(\mathrm{R}^{2}\right)$ in order to estimate the accuracy of the model. The model was said to be valid when $\mathrm{R}^{2}$ was more than 0.80 (Joglekar and May, 1987), the value of the absolute analysis of average deviation (AADM) near to 0 (Bas and Boyac, 2007).

\section{Results and discussion}

\section{Chemical characterization}

Chemical characterization shows the nutritional properties and an orientation on the functional valorization of food products. Results on some physico - chemical properties of the defatted flours of the two fruits indicate significant differences $(p<0.05)$. Proteins represent the major constituent of the two defatted flours with 39.98 and $36.89 \mathrm{~g} \%$ of dry weight (DW) for $R$. heudelotii and $T$. conophorum respectively. This justifies the nutritional and functional interests attached to their defatted flours (Tchiégang and Mezajoug Kenfack, 2003; Enujiugha, 2003; Tchiégang et al., 2006; Mezajoug Kenfack, 2010). These values are lower than those reported by Tchiégang et al. (2006) who indicated more than $50 \%$ of proteins for the two Euphorbiaceae from different localities in Cameroon. This difference may be due to the particle size of flours, when different sieves were used (Mezajoug Kenfack, 2010). Crude fibers content of different types of defatted flours was less than $6 \%$. Similar results were reported by Mezajoug Kenfack (2010).

The presence of carbohydrates is one of the main characteristics of oleaginous plants. T. conophorum and $R$. heudelotii defatted flours have 14.05 and $11.15 \mathrm{~g} \%$ DW of total carbohydrates respectively. $R$. heudelotii defatted flour exhibited higher ash content $(13.34 \mathrm{~g} \%$ DW) than T. conophorum defatted flour $(4.75 \mathrm{~g} \% \mathrm{DW})$. The large difference between the ash content of the two samples was observed (Tchiégang et al., 2006; Mezajoug Kenfack, 2010). A low value of ash $(5.68 \mathrm{~g} \%$ DW) was mentioned in Nigerian $T$. conophorum defatted cake (Ayoola et al., 2011). The defatted flours of the two samples also had secondary metabolic compounds like phenolic compounds and phytic acid, which reduce the availability of protein and affect their functional properties in food products (Donlaporn and Warapot, 2011). $R$. heudelotii defatted flour contained the highest quantity of phytate $(11.97 \mathrm{mg} \%$ DW) compared to T. conophorum $(8.52 \mathrm{mg} \% \mathrm{DW})$. The values of total phenolic compounds ( $\mu \mathrm{g} / 100 \mathrm{~g} \mathrm{DW})$ were very low in the defatted flours of $R$. heudelotii (159.04\%) and $T$. conophorum (168.62\%). These values were very different from those obtained by (Mezajoug Kenfack, 2010) who indicated more than $4 \mathrm{mg} \% \mathrm{DW}$ of phenolic compounds for the two Euphorbiaceae.

\section{Solubility of the defatted flours}

The solubility was carried out using a factorial design to test the effects of $\mathrm{pH}$, temperature and ionic strength. Table 3 shows the experimental and theoretical results of the 10 experiments defined in Table 2.

Modeling: Using the experimental results, equations of the first degree were established to estimate the relationship between the solubility of the defatted flours and variables.

For protein solubility, the models of R. heudelotii $\left(\mathrm{Y}_{1}\right)$ and T. conophorum $\left(\mathrm{Y}_{2}\right)$ could be expressed respectively as:

$$
\begin{gathered}
\mathrm{Y}_{1}=27.79+7.812 \mathrm{pH}-0.945 \mathrm{~T}+45.654 \mathrm{CaCl}_{2}-0.034 \mathrm{pH} \times \mathrm{T}-4.556 \mathrm{pH} \times \mathrm{CaCl}_{2}+1.651 \mathrm{~T} \times \mathrm{CaCl}_{2} ; \mathrm{R}^{2}=91.82 \\
\mathrm{Y}_{2}=20.303+14.542 \mathrm{pH}-0.623 \mathrm{~T}-49.2 \mathrm{CaCl}_{2}-0.173 \mathrm{pH} \times \mathrm{T}-8.475 \mathrm{pH} \times \mathrm{CaCl}_{2}+1.96 \mathrm{~T} \times \mathrm{CaCl}_{2} ; \mathrm{R}^{2}=87.98
\end{gathered}
$$

For R. heudelotii $\left(\mathrm{Y}_{1}\right)$ and T. conophorum $\left(\mathrm{Y}_{2}\right)$, the mathematical models in the case of phytate solubility could be expressed as:

$$
\begin{gathered}
\mathrm{Y}_{1}=155.46-15.071 \mathrm{pH}-1.091 \mathrm{~T}-5.352 \mathrm{CaCl}_{2} \quad 0.133 \mathrm{pH} \times \mathrm{T}+1.233 \mathrm{pH} \times \mathrm{CaCl}_{2}-0.088 \mathrm{~T} \times \mathrm{CaCl}_{2} ; \mathrm{R}^{2}=99.86 \\
\mathrm{Y}_{2}=121.571-8.779 \mathrm{pH}-0.951 \mathrm{~T}+1.808 \mathrm{CaCl}_{2}+0.131 \mathrm{pH} \times \mathrm{T}+0.292 \mathrm{pH} \times \mathrm{CaCl}_{2}-0.124 \mathrm{~T} \times \mathrm{CaCl}_{2} ; \mathrm{R}^{2}=99.88
\end{gathered}
$$


Table 3. Experimental and theoretical values of solubility.

\begin{tabular}{|c|c|c|c|c|c|c|c|c|c|c|c|}
\hline \multirow[b]{3}{*}{$A_{\mathrm{cos}}$} & \multirow{2}{*}{\multicolumn{3}{|c|}{ Experimental values }} & \multicolumn{4}{|c|}{ Protein solubility } & \multicolumn{4}{|c|}{ Phytate solubility } \\
\hline & & & & \multicolumn{2}{|c|}{ R. heudelotii } & \multicolumn{2}{|c|}{ T. conophorum } & \multicolumn{2}{|c|}{ R. heudelotii } & \multicolumn{2}{|c|}{ T. conophorum } \\
\hline & $\mathrm{X}_{1}$ & $\mathrm{X}_{2}$ & $\mathrm{X}_{3}$ & $Y_{\exp }$ & $Y_{\text {theo }}$ & $Y_{\exp }$ & $Y_{\text {theo }}$ & $Y_{\exp }$ & $Y_{\text {theo }}$ & $Y_{\text {exp }}$ & $Y_{\text {theo }}$ \\
\hline 1 & 4 & 60 & 0.3 & 1.15 & 4.79 & 4.21 & 9.93 & 59.38 & 60.12 & 59.20 & 59.45 \\
\hline 3 & 4 & 35 & 0.3 & 23.06 & 19.42 & 33.83 & 28.10 & 75.41 & 74.67 & 71.33 & 71.07 \\
\hline 4 & 9 & 35 & 1.1 & 26.31 & 22.66 & 18.09 & 12.36 & 27.44 & 26.69 & 50.86 & 50.61 \\
\hline 5 & 4 & 60 & 1.1 & 36.57 & 32.93 & 43.26 & 37.53 & 56.26 & 55.52 & 56.13 & 55.87 \\
\hline 7 & 4 & 35 & 1.1 & 10.89 & 14.53 & 10.78 & 16.50 & 71.11 & 71.84 & 69.72 & 69.98 \\
\hline 8 & 9 & 35 & 0.3 & 42.13 & 45.77 & 52.14 & 57.86 & 23.85 & 24.58 & 50.28 & 50.54 \\
\hline 9 & 6.5 & 47.5 & 0.7 & 23.68 & 27.79 & 44.84 & 20.30 & 26.79 & 155.45 & 51.01 & 121.57 \\
\hline 10 & 6.5 & 47.5 & 0.7 & 22.74 & 27.79 & 43.60 & 20.30 & 27.08 & 155.45 & 51.45 & 121.57 \\
\hline
\end{tabular}

$\mathrm{X}_{1}(\mathrm{pH}), \mathrm{X}_{2}$ (temperature), $\mathrm{X}_{3}$ (salt concentration), $\mathrm{Y}_{\mathrm{exp}}$ (experimental result values), $\mathrm{Y}_{\text {theo }}$ (theoretical values coming from mathematical models).

The determination coefficient $\left(\mathrm{R}^{2}\right)$ of an equation gives the degree of linkage between the independent and dependent variables studied (Goupy and Creighton, 2006).

For all the mathematical models the high values of determination coefficients $\left(R^{2}\right)$ are adequate to characterize the solubility of the defatted flours. This analysis coupled to AADM values (Bas and Boyac, 2007) and bias factor (Ross, 1999) is necessary to estimate the significance level of the models. In the case of phytate solubility the AADM values $(0.001$ and 0.002 for $R$. heudelotii and $T$. conophorum respectively) and bias factor (1.00 and 0.99 respectively) allowed for the validation of the models. At the same time, the AADM values $(0.039$ and 0.026 for $R$. heudelotii and $T$. conophorum respectively) and bias factor (1.18 and 1.14 respectively) confirm the suitability of the models corresponding to protein solubility.

The effects of different model factors were linear $(\mathrm{pH}, \mathrm{T}$, $\left.\mathrm{CaCl}_{2}\right)$ or combined $\left(\mathrm{pH} \times \mathrm{T}, \mathrm{pH} \times \mathrm{CaCl}_{2}, \mathrm{~T} \times \mathrm{CaCl}_{2}\right)$. According to the analysis of variance (ANOVA), the effects were statistically considered significant $(p<0.05)$ or not $(p>0.05$ ), considering probability values (less than 1). In addition, the sign of the coefficient of the models also specifies whether the influence is negative or positive when the solubility decrease or increase respectively.

Among the parameters of the solubility, $\mathrm{pH}$ is the only factor which has an influence on ionization of phytate and protein molecules. $\mathrm{pH}$ has a positive effect $(p>0.05)$ on protein solubility and influenced the solubility of phytate in the defatted flours of the both plants negatively $(p<0.05)$. This could be ascribed to the higher solubility of protein and lower solubility of phytate in alkaline solution. Proteins are more soluble in alkaline medium because interactions between protein and water molecules increase, while phytate precipitate when the concentration of sodium due to the addition of $\mathrm{NaOH}$ increases (de Rham and Jost, 1979; Graf, 1986). This difference between protein solubility and phytate solubility could help to extract more protein and eliminate the majority of phytate. This confirms the findings in sunflower seed protein (Bulmaga et al., 1989).

\section{Influence of $\mathrm{pH}$ and $\mathrm{CaCl}_{2}$ concentration on phytate - protein binding in protein extracts of two} Euphorbiaceae: Contours plots (Fig. 1) show the combined effect of $\mathrm{pH}\left(X_{1}\right)$ and $\mathrm{CaCl}_{2}$ concentrations $\left(X_{3}\right)$ on protein solubility of $R$. heudelotii and $T$. conophorum defatted flours. For the both species, the reduction of $\mathrm{CaCl}_{2}$ concentrations associated to increasing of $\mathrm{pH}$ raises the protein solubility. Increasing protein solubility could be explained by hydration of protein molecules in high $\mathrm{pH}$ and lower salt concentrations (salting - in effect) (Ahmed et al., 2012). However, the high ash content of $R$. heudelotii could explain the low solubility of their proteins. Indeed, it is possible for these minerals to form insoluble complexes with proteins. The same behavior of protein solubility of $R$. heudelotii and T. conophorum, due to changes of $\mathrm{pH}$ and salt concentrations was reported (Tchiégang et al., 2006; Mezajoug Kenfack, 2010).

Proteins of the two defatted flours are more soluble at $\mathrm{pH}$ 9 in $0.3 \mathrm{M} \mathrm{CaCl}_{2}$ solution and less soluble at $\mathrm{pH} 4$. Protein solubility is lower at the isoelectric $\mathrm{pH}$ of the proteins. At this $\mathrm{pH}$, equality between positive and negative charges inside the protein molecules leads to 
protein precipitation. The lower protein solubility of the defatted flours at $\mathrm{pH} 4$ was earlier found (Tchiégang and Mezajoug Kenfack, 2003). The synergistic effect of salt and $\mathrm{pH}$ on protein solubility suggests their importance in the protein extraction. Maximum solubility conditions are required to extract more proteins. Minimum solubility conditions are necessary for their recovery
(Moure et al., 2006). Phytic acid - protein complexes are formed during solubilization of the defatted flours. These complexes reduce the recovery of protein during extraction. To increase the recovery of protein during extraction, it is important to define the solubility conditions that could allow to extract the maximum protein and to eliminate the majority of phytic acid.

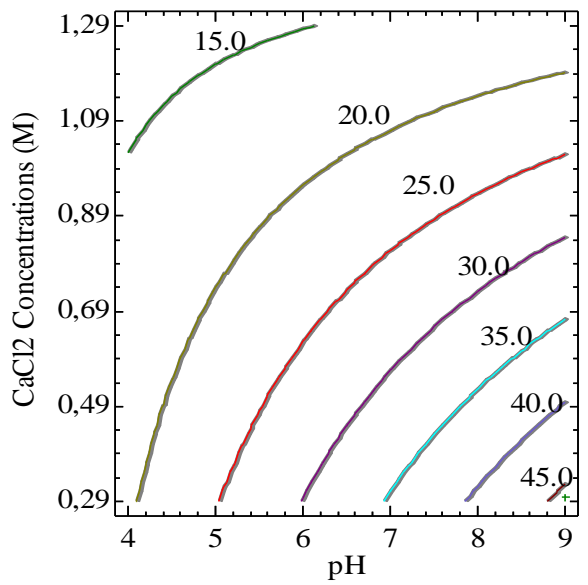

(A)

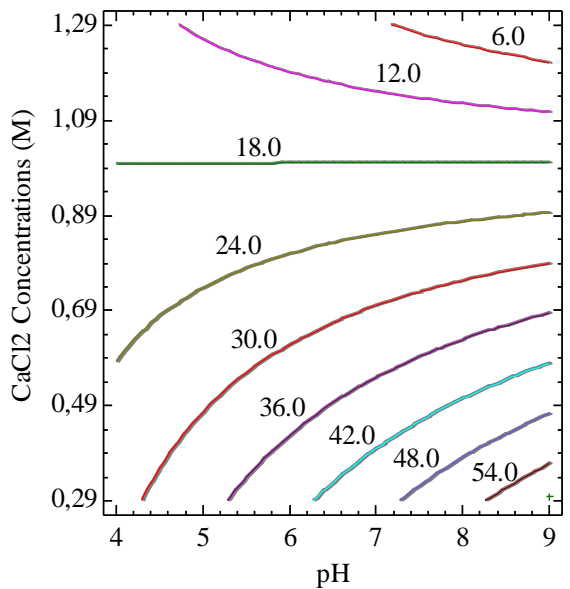

(B)

Fig. 1: Contours plots of $\mathrm{pH}\left(X_{1}\right)$ and $\left[\mathrm{CaCl}_{2}\right]\left(X_{3}\right)$ on protein solubility of $R$. heudelotii (A) and T. conophorum (B) defatted flours (temperature was kept constant at $35^{\circ} \mathrm{C}$ ).

Fig. 2 shows the conjugated effect of $\mathrm{pH}\left(X_{1}\right)$ and $\mathrm{CaCl}_{2}$ concentrations $\left(X_{3}\right)$ on phytate solubility of the two defatted flours. Increasing $\mathrm{pH}$ and $\mathrm{CaCl}_{2}$ concentrations reduce phytate solubility of the defatted cakes. Coupled to raising of $\mathrm{CaCl}_{2}$ concentrations, phytate solubility is higher at $\mathrm{pH} 4$ and lower at $\mathrm{pH} 9$ (Fig. 2), in contrast to behavior of protein solubility (Fig. 1). These results show that $\mathrm{CaCl}_{2} \quad 0.3 \mathrm{M}$ and $\mathrm{pH} 9$ are the appropriate

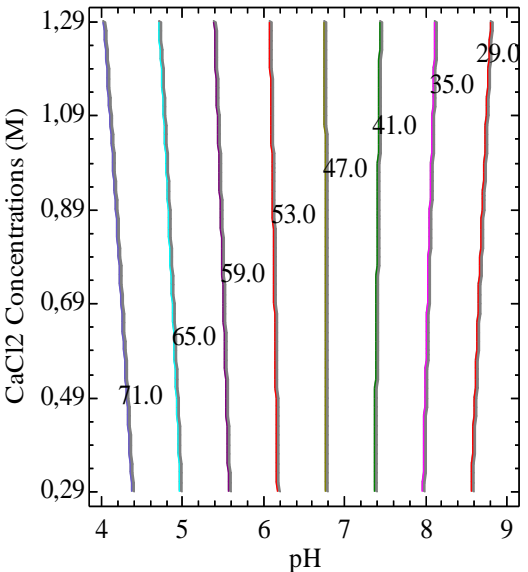

(A) conditions to reduce the phytic acid - protein complexes in sight of extracting the maximum of protein. The lower solubility of phytate at $\mathrm{pH} 9$ could be explained by the breaking of phytate - cation - protein complexes to form insoluble calcium - phytate complexes and soluble proteins. Reduction of phytate solubility at alkaline medium was also observed on soybean (de Rham and Jost, 1979) and sunflower (Bulmaga et al., 1989).

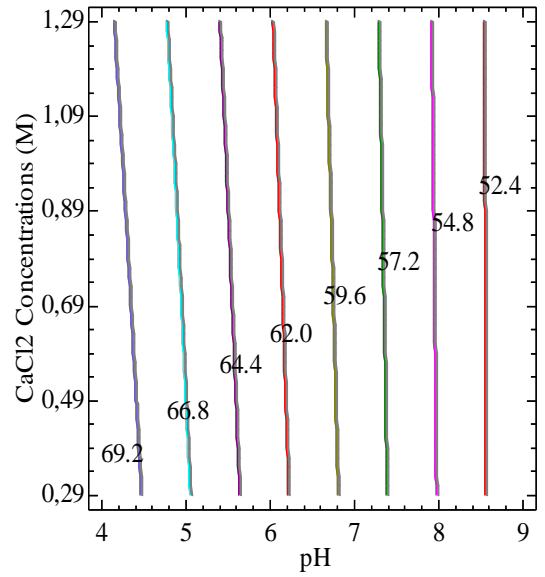

(B)

Fig. 2: Contours plots of $\mathrm{pH}\left(X_{1}\right)$ and $\left[\mathrm{CaCl}_{2}\right]\left(X_{3}\right)$ on phytate solubility of $R$. heudelotii (A) and T. conophorum (B) defatted flours (temperature was kept constant at $35^{\circ} \mathrm{C}$ ). 


\section{Conclusion}

Mathematical models derived from factorial design used in this study indicated conditions for protein extraction from $R$. heudelotii and $T$. conophorum defatted flours. Protein and phytate solubility conditions defined in this experiment were considered in selected range of $\mathrm{pH}$ and salt concentration at $35^{\circ} \mathrm{C}$.

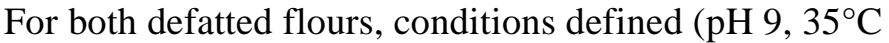
and $0.3 \mathrm{M} \mathrm{CaCl}_{2}$ ) solubilize $42-52 \%$ of proteins. Maximum phytate solubilization was observed at the ioselectric point of proteins $(\mathrm{pH} 4)$. Nevertheless, the amino acids composition of protein extracts must be analyzed in sight to study their nutritional quality.

\section{Conflict of interest statement}

Authors declare that they have no conflict of interest.

\section{References}

Ahmed, S. H., Babiker, E. E., Mohamed Ahmed, I. A., Eltayeb, M. M., Ahmed, S. O., Faridullah., 2012. Effect of sodium chloride concentration on the functional properties of selected legume flours. Afr. J. Food Agric. Nutr. Dev. 12(6), 6700-6714.

AOAC, 1999. Official Methods of Analysis of the Association of the Official Analytical Chemists (Ed.: Elrich, K.). Washington, DC.

Ayoola, P. B., Onawumi, O. O., Faboya, O. O. P., 2011. Chemical evaluation and nutritional values of Tetracarpidium conophorum (Nigerian Walnut) seeds. J. Pharmaceut. Biomed. Sci. 11(15), 1-5.

Bas, D., Boyac, I. H., 2007. Modeling and optimization I: Usability of response surface methodology. J. Food Engg. 78, 836-845.

Bulmaga, V.P., Lapteva, N. A., Vaintraub, I. A., 1989. The effect of phytate on the solubility of the sunflower seed proteins. Die Nahrung. 33(2), 161-165.

de Rham, O., Jost, T., 1979. Phytate-protein interactions in soybean extracts and low-phytate soy protein products. J. Food Sci. 44(2), 596-600.

Devani, M.B., Shishoo, J.C., Shah, S.A., Suhagia, B.N., 1989.Spectrophotometrical method for determination of nitrogen in Kjeldahl digests. J. Assoc. Off. Anal. Chem. 72, 953-956.

Donlaporn, S., Worapot, S., 2011. Toxic compound, antinutritional factors and functional, properties of protein isolated from detoxified Jatropha curcas seed cake. Int. J. Mol. Sci. 12(1), 66-77.

Dubois, M., Gilles, K. A., Hamilton, J. K., Rebers, P. A.,
Smith, F., 1956. Colorimetric method for determination of sugars and related substances. Anal. Chem. 28(3), 350-356.

Enujiugha, V. N., 2003. Chemical and functional characteristics of Conophor nut. Pak. J. Nutr. 2, 335-338.

Godon, B., 1996. Technologie d'extraction et de purification des matières protéiques végétales. Dans Protéines Végétales. $2^{\text {nd }}$ Edn. Lavoisier, Techniques et Documentation, Paris (France). 666p.

González-Pérez, S., Vereijken, J. M., Van Koningsveld, G. A., Gruppen, H., Voragen, A. G. J., 2005. Physicochemical properties of $2 \mathrm{~S}$ albumins and the corresponding protein isolate from sunflower (Helianthus annuus). J. Food Sci. 70(1), 98-103.

Goupy, J., Creighton, L., 2006. Introduction aux plans d'expériences. (3 ${ }^{\text {ème }}$ Edn). Dunod, Paris. 336p.

Graf, E., 1986. Phytic Acid: Chemistry and Applications. An Overview. Pilatus Press, Minneapolis, Minnesota.

Greiner, R., Konietzny, U., Jany, K.D., 2006. Phytate - an undesirable constituent of plant-based foods? J. Ernährungsmedizin. 8(3), 18-28.

Joglekar, A. M., May, A. T., 1987. Product excellence through design of experiment. Cereal Foods World. 32, 857-886.

Makkar, H.P.S., Blummel, M., Borowy, N.K., Becker, K., 1993. Gravimetric determination of tannins and their correlations with chemical and protein precipitation methods. J. Sci. Food Agric. 61, 161-165.

Mezajoug Kenfack, L.B., 2010. Propriétés nutritionnelles et fonctionnelles des protéines de tourteaux, de concentrats et d'isolats de Ricinodendron heudelotii (Bail.) Pierre ex Pax et de Tetracarpidium conophorum (Müll. Arg). Thèse présentée à l'Institut National Polytechnique de Lorraine (INPL) pour obtenir le grade de Docteur de l'INPL et Docteur Ph.D de l'Université de Ngaoundéré, Spécialité : Procédés Biotechnologiques et Alimentaires. $226 \mathrm{p}$.

Moure, A., Sineiro, J., Domínguez, H., Parajó, J. C., 2006. Functionality of oilseed protein products: A review. Food Res. Int. 39, 945-963.

Ross, T., 1999. Indices for performance evaluation of predictive models in food microbiology. J. Appl. Bacteriol. 81, 501-508.

Sri Kantha, S., Hettiarachchy, N. S., Erdman, J. W., 1986. Nutrient, antinutrient contents, and solubility profiles of nitrogen, phytic acid, and selected minerals in winged bean flour. Cereal Chem. 63(1), 9-13.

Tchiégang, C., Mezajoug Kenfack, L. B., 2003. Influence of $\mathrm{pH}$, temperature and ionic strength on some functional properties of defatted flour from Ricinodendron heudelotii (Bail.) and Tetracarpidium conophorum (Müll. Arg). J. Technol. 1(3), 133-138.

Tchiégang, C., Mezajoug Kenfack, L. B., Tenin, D., 
Ndjouenkeu, R., 2006. Physicochemical and functional properties of defatted cakes from two Euphorbiaceae from Cameroun: Ricinodendron heudelotii (Bail.) and Tetracarpidium conophorum (Müll. Arg.). J. Food Technol. 4(2), 96-100.
Vaintraub, I. A., Lapteva, N. A., 1988. Colorimetric determination of phytate in unpurified extracts of seeds and the products of their processing. Anal. Biochem. $175,227-230$.

\section{How to cite this article:}

Mezajoug Kenfack, L. B., Tapimali Tsamé, D., Tchiégang, C., 2016. Effect of protein-phytate interactions on the solubility of Ricinodendron heudelotii (Bail.) and Tetracarpidium conophorum (Müll. Arg.) defatted flours. Int. J. Curr. Res. Biosci. Plant Biol. 3(8), 12-18. doiः http://dx.doi.org/10.20546/ijcrbp.2016.308.002 